\title{
A Comparative Study on Child Rights Recognition and Child- Friendly Cities by Region
}

\author{
Soon-Young Lee ${ }^{1}$, Mi-Na Lee ${ }^{2}$ \\ ${ }^{1}$ The Doctor's Course, Department of Culture, Chosun University, South Korea, 74-lsy@ hanmail.net \\ ${ }^{2}$ Professor, Department of Welfare Counseling Convergence, Kwangshin University, Gwangju, South \\ Korea,lmn4780@naver.com
}

Corresponding author: Mi-Na Lee

\begin{abstract}
This study was conducted to find out how children in each region recognize children's rights by comparing child rights recognition and child-friendly city development projects according to regions. The child-friendly city is based on the four main goals of children's rights announced by UNICEF: the right to live, the right to develop, the right to protect, and the right to participate. This paper studied a child's family environment in detail in order to find a constructive and concrete plan for creating a childfriendly city. The survey used a questionnaire for 1,423 children residing in $\mathrm{G}$ city and $\mathrm{N}$ city. In $\mathrm{G}$ city, the respondents were 505 children (male: 277 , female: 228 ), $54.83 \%$ and $45.17 \%$, respectively, while, in the $\mathrm{N}$ city there were 918 children (male: 476 , female: 442 ), $51.80 \%$ and $48.20 \%$, respectively. The following are the results of the study; First, in the field of play and leisure, they answered that there is no activity space that can be used by children with physical disabilities and that participation and provision of various cultural and religious programs need improvement in the future. Second, it is necessary to increase the participation rate since the level of participation of children, such as policies for children, is the lowest in the community. Third, in the aspect of safety and protection, the efforts to create a safe physical environment along with positive provisions such as security and housing protection and media usage are necessary. Fourth, in the field of health and social services, it is necessary to provide children's mental health services and to solve environmental problems. Lastly, in the field of educational environment, it is necessary to provide education for children's human rights awareness and respect. Fifth, in the field of educational environment, there was an opinion that it was necessary to provide education for children's human rights awareness and respect. As a result of comparison by region, this suggests that in the aspect of child-friendly city creation, it is necessary to approach complex interventions and measures in consideration of various aspects such as educational environment, safety and protection, play and leisure, health and social services, etc. It can be called the result.
\end{abstract}

Keywords: Recognition of Child Rights, Child-friendly Cities, Regional Comparison, Creation of a Friendly City, UN Convention on the Rights of the Child

\section{Introduction}

With the rapid development of industrialization and urbanization today, many children are now residing in the cities. The continued urbanization rate will accelerate and by $2025,60 \%$ of the world's children will live in urban environments[1]. As a result, children's daily experiences are created in urban environments and face various positive and negative aspects of urbanization[2].

Received: October 09, 2020; 1st Review Result: November 26, 2020; 2nd Review Result: January 11, 2021 Accepted: February 26, 2021 
On the positive side of the urban environment, it is easier to experience and grow in physical environments, such as advanced transportation systems, efficient services, residential stability, and the use of clean drinking water and toilets[3]. However, negative aspects such as the narrowness of residential space, environmental pollution, lack of play space, and indifference to community neighbors due to the overcrowding of the population can undermine the satisfaction of children's lives. In addition, cities are also threatened with life due to various crimes, violence, and traffic accidents in dense areas[4].

The developed urban environment provides children with high-quality basic health services, education, leisure activities, and provides a better physical environment for children to grow, such as advanced transportation, clean sanitation, and efficient electrical and heating facilities[5]. However, environmental pollution, traffic congestion, lack of play space, loss of green space, anonymity of local residents, and adult-oriented urban policies have a negative impact on children's development and threaten their lives[5]. The international community has been making a lot of efforts to improve the environment with interest in creating an optimal living environment for children who are suffering from a health problem. In line with the expansion of women's social advancement, the low birth rate began as a solution to the inadequate social environment of child-care. As such, the concept of "child-friendly city" has been established for children from the perspective of child welfare, and it is spreading throughout Korea and around the world. The purpose of child-friendly cities is to minimize the negative effects of each community and urban environment on the growth and development of children and to lead them toward sustainable development through the promotion of children's rights.

This is to create an environment in which all children are protected with the rights to live and to live up to their individual potential in a safe and clean environment It also refers to living happily and fully enjoying the rights of children in an environment that allows them to receive sufficient social services. According to the legal standards of Child Welfare Act, children are those under 18 years of age. Child Friendly Cities (CFC) refers to a city in which the four universal rights of children - the right to live, to develop, to protect, and to participate are fully realized in accordance with the ideology of the United Nations Convention on the Rights of the Child[6].

UNICEF, which has been actively engaged in child-friendly city movements around the world since 1996, defined child-friendly cities as 'establishing urban and community systems systematically and systematically at the local government level to fully guarantee the rights of children'.

In addition, a child-friendly environment is the creation of a resilient, secure, capable, and habitable environment for the healthy growth and development of children (UNICEF, 2004).

First, it serves as the foundation for implementing consumer-oriented policies.

Second, a more efficient policy plan can be established by clearly identifying children's needs and opinions.

Third, it can reflect children's needs and perspectives in more diverse areas.

Fourth, it can improve the ability and qualities of a child to grow into a democratic citizen. As such, various activities in children's daily lives are increasingly restricted by changes in the environment in the city. Indeed, the most basic activities of most children, such as running errands alone or visiting friends' homes, are also limited by their parent, and are freely roaming the community (in the recent years, the international community has made great efforts to improve with interest in creating an optimal living environment for children who are suffering from difficulties in growth development to grow healthy). The experience of enjoying freedom is also fading[7]. In particular, 'independent mobility' can be defined as an opportunity to roam independently without guidance and supervision of adults, and this free movement has proved to be a very important factor affecting the development of children's physical and emotional development[8]. Currently, 1,300 cities in 30 countries around the world are seeking more advanced ways to create a child-friendly city by receiving certification and sharing cases. As such, efforts are being made to create an environment suitable for the growth environment of children in many countries and cities. Korea also continues to discuss the creation of an environment for the satisfaction 
'of children's lives in accordance with the child policies of each community. Korea is certifying a childfriendly city to create a community where the Convention on the Rights of the Child is realized at the UNICEF Korea Committee, which was established on January 1, 1994. In November 2013, it was certified as Korea's first child-friendly city in Seongbuk-gu, Seoul, and since then, it has been certified as a child-friendly city in Wanju-gun as a model for small and medium-sized city. So far, 99 local governments across the country are creating UNICEF child-friendly cities. These efforts played an important role in enhancing the satisfaction and happiness of children's lives. The child-friendly city movement has a significant impact on children's life satisfaction, and happiness at the community level. In childhood development, community and residential regional effects are distinguished in functional, environmental, and structural aspects, which affect community members' physical and mental health[9]. In fact, children living in poor environmental areas had higher levels of anxiety and depression than children living in non-viable environments[10]. Self-concepts were low and community crime rates were high[11]. In addition, the disorder of the physical environment, such as the destruction of harmful environments and facilities, the safety of walking and the presence of parks have a negative impact on physical and mental health[12]. Child-friendly living conditions have been shown to have a significant impact on children's physical and mental health[13]. Not only does it also create a social and physical environment for the community. Community involvement and awareness, attitudes and interactions with neighbors are also reported to affect children's psychological well-being[14]. However, poor housing and community conditions negatively affect children's physical and mental health. Thus, the economic, functional, and structural environment of the community is affecting children and these community social support resources can be a result of raising the level of satisfaction with their lives. This study was intended to examine the influence of macro-environment on the satisfaction of children's lives, such as child-friendly cities. Therefore, the results of the study is intended to help children live happily, suggesting practical improvements and changes in child-friendliness in terms of community support for development and growth.

The research issues of this study are as follows.

First, how is the recognition of children's rights in six major areas of child-friendly cities?

Second, what is the level of satisfaction in child-friendly cities by region?

\section{Research Method}

\subsection{The Subject of Study}

The data used in this study were gathered through a survey of child-friendly cities in the $\mathrm{G}$ and $\mathrm{N}$ areas in 2019. The samples were randomly chosen from the $\mathrm{G}$ and $\mathrm{N}$ areas, and the survey period was from September 23, 2019 to October 29, 2019. This study used the self-reporting question presented by the Korean Committee for UNICEF. The total number of people surveyed in the question is 1,423 children from $\mathrm{G}$ and $\mathrm{N}$ cities Of the 505 children in $\mathrm{G}$ city, 277 (54.83 percent) were male, 228 (45.17 percent) were female, while in $\mathrm{N}$ city, 476 (51.80 percent) were male and 442 (48.20 percent) were female.

\subsection{Measurement of Data}

The dependent variables of this study were measured for life satisfaction, and the independent variables were the six major areas of play and leisure, participation and civic awareness, safety and protection, health and social services, educational environment, and home environment. 


\subsubsection{Six Major Fields of Child-Friendly Cities}

The Korean Committee of UNICEF translated the measure proposed by UNICEF to create a childfriendly city and supplemented it to suit local characteristics. UNICEF developed and used measures based on the right to survive, protect,develop, and participate in six major areas of child-friendly cities. The questions consist of play and leisure ( 7 questions), participation and civic awareness (6 questions), safety and protection (15 questions), health and social services (8 questions), educational environment (23 questions), and family environment (5 questions). Each question consists of a three-point three-point Likert scale, where one point corresponds to "not at all" and three points for "very". The higher the score in each question, the higher the awareness of children's rights.

\subsubsection{Child-Friendly City Satisfaction Level}

The level of satisfaction in life was measured according to the satisfaction level of the residential environment in the community by checking whether the services provided in each area for creating a child-friendly city were affecting the level of satisfaction of children. Each item is a measure of a seven points scale, and the higher score, the higher level of satisfaction a child has with living life.

\subsubsection{Characteristics of Study Subjects}

Among the characteristics of the study subjects were sex, school, school grade, date of birth, residential area, and family. For sex, ' 0 ' for males and '1' for females. Question types are single and openended question types.

\subsection{Data Analysis}

This study used SPSS 25.0 Statistical Program for data analysis. Frequency analysis and percentages were calculated to analyze the demographic characteristics, and technical statistics were performed to identify the overall variable characteristics. Begin sentence with article A-verification was conducted to examine the differences in major variables according to the characteristics. In addition, a random analysis of repeat measurements was performed between groups according to the child's satisfaction items, and a one-sided analysis was performed for each satisfaction item. The final data was obtained by minimizing non-sampling error through processes such as editing, coding, cleaning, and data processing.

\section{Results of the Study}

\subsection{Characteristics of the Study Subjects}

The characteristics of the subjects were investigated by the sex, grade, etc. of the children. The status of the children is as shown in [Table 1].

[Table 1] The Status of the Children (Unit: \%)

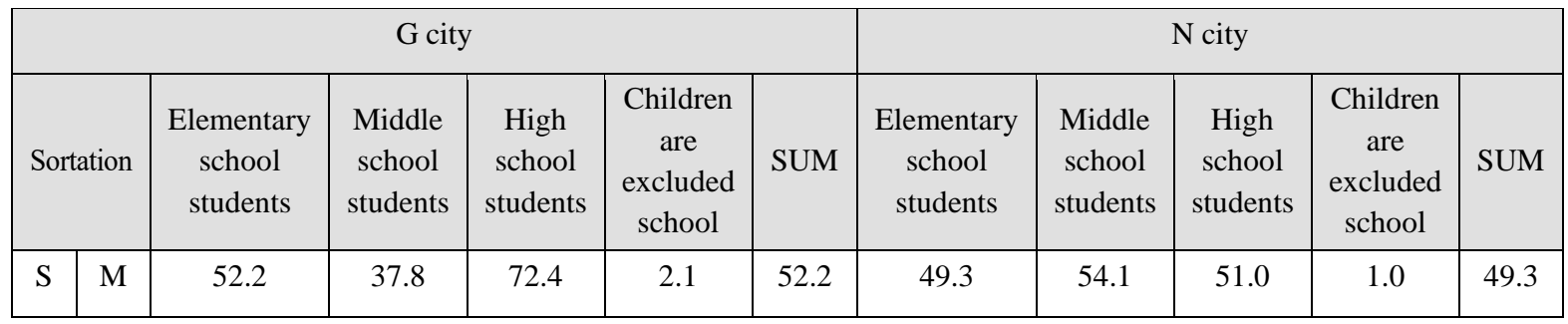




\begin{tabular}{|l|l|l|l|l|l|l|l|l|l|l|l|}
\hline $\mathrm{E}$ & $\mathrm{F}$ & 47.8 & 62.2 & 24.2 & 1.3 & 47.8 & 50.7 & 44.2 & 49.1 & 0.7 & 50.7 \\
$\mathrm{X}$ & & & & & & & & & & &
\end{tabular}

Among the 505 respondents in G city, in elementary school students, $52.2 \%$ are male and $47.8 \%$ are female; in middle school, $37.8 \%$ are male and $62.2 \%$ are female; in high school, $72.4 \%$ are male and $24.2 \%$ are female. Among the 918 respondents in $\mathrm{N}$ city, $49.3 \%$ are male and $50.7 \%$ are female among the elementary school students, $54.1 \%$ are male and $44.2 \%$ are female among the middle school students, and $51.0 \%$ are male and $49.1 \%$ are male in high school.

\subsection{Recognition of Children's Rights in Each of the Six Major Areas}

\subsubsection{Awareness of Play and Leisure Areas}

The level of rights recognition for detailed services of play and leisure was identified. The play and leisure areas consist of questions about whether there is a space available for children in community housing and, if so, whether the space is safe. The level of rights awareness of the play and leisure areas of children living in $\mathrm{G}$ city and $\mathrm{N}$ city as shown in Table 2 of the six areas of child-friendly cities.

[Table 2] The Six Areas of Child-friendly Cities (Unit: \%)

\begin{tabular}{|c|c|c|c|c|c|c|c|c|c|}
\hline & & \multicolumn{4}{|c|}{ G city } & \multicolumn{4}{|c|}{$\mathrm{N}$ city } \\
\hline Num & Questions & $\begin{array}{l}\text { Elemen } \\
\text { tary } \\
\text { students }\end{array}$ & $\begin{array}{l}\text { Middle and } \\
\text { high school } \\
\text { students }\end{array}$ & $\begin{array}{c}\text { Except } \\
\text { school } \\
\text { education }\end{array}$ & Sum & $\begin{array}{l}\text { Elementary } \\
\text { students }\end{array}$ & $\begin{array}{l}\text { Middle and } \\
\text { high school } \\
\text { students }\end{array}$ & $\begin{array}{c}\text { Except } \\
\text { school } \\
\text { education }\end{array}$ & Sum \\
\hline 1 & $\begin{array}{l}\text { Able to use time for taking } \\
\text { a rest }\end{array}$ & 2.82 & 2.65 & 2.70 & 2.72 & 2.73 & 2.67 & 3.00 & 2.80 \\
\hline 2 & $\begin{array}{l}\text { Safe place for taking a time } \\
\text { (ex, playground, fitness } \\
\text { facility etc.) }\end{array}$ & 2.79 & 2.33 & 2.63 & 2.58 & 2.68 & 2.53 & 2.00 & 2.40 \\
\hline 3 & $\begin{array}{l}\text { Disable children can use } \\
\text { the playground. }\end{array}$ & 2.09 & 2.03 & 2.62 & 2.25 & 2.72 & 2.45 & 2.33 & 2.50 \\
\hline 4 & $\begin{array}{l}\text { There is a place that I could } \\
\text { feel and touch the nature } \\
\text { (tree, forest etc) }\end{array}$ & 2.76 & 2.63 & 2.62 & 2.67 & 2.04 & 1.96 & 1.50 & 1.83 \\
\hline 5 & $\begin{array}{l}\text { Various cultural/religious } \\
\text { events are held where I can } \\
\text { participate or see. }\end{array}$ & 2.52 & 2.27 & 2.32 & 2.37 & 2.16 & 2.21 & 1.00 & 1.79 \\
\hline 6 & $\begin{array}{l}\text { There are outside school } \\
\text { programs, meetings and } \\
\text { activities that I can } \\
\text { participate. }\end{array}$ & 2.66 & 2.31 & 2.35 & 2.44 & 2.27 & 2.19 & 2.00 & 2.15 \\
\hline 7 & $\begin{array}{l}\text { A safe place to play } \\
\text { (playgrounds) is just } \\
\text { around the house. }\end{array}$ & 2.80 & 2.73 & 2.67 & 2.73 & 2.67 & 2.54 & 1.67 & 2.29 \\
\hline
\end{tabular}

※ Average score: $1=$ Not at all, $2=$ Sometimes, $3=$ Very

$※$ The rate of positive answer : Percentage of responses to positive responses (very)

The analysis found that the lowest level of recognition of rights in the play and leisure areas of children living in $\mathrm{G}$ city was 'the absence of space available to children with physical disabilities'. As a 
result of this similar entry, 'providing various cultural/religious programs available to the community' was not high. In the lowest level of play and leisure for children living in $\mathrm{N}$ city, 'various cultural/religious events are held where they can participate or watch' was the lowest, followed by 'I have access to nature' and lack of 'out-of-school programs, meetings and activities'. In other words, the lack of space available to children with physical disabilities and the participation and provision of various cultural/religious programs have not been shown to be high, so future improvements and efforts will be needed.

\subsubsection{Awareness of the Domain of Participation and Civic Awareness}

Among the six areas of child-friendly cities, the level of rights recognition for participation and civic awareness was identified. The area of participation and civic awareness is making decision process that determines important matters in the community, consisting of whether children's opinions are reflected and whether they actively provide important matters in the region related to children. The level of recognition of children's rights in the area is shown in [Table 3].

[Table 3] The Level of Recognition of Children's Rights in the Area (Unit : \%)

\begin{tabular}{|c|c|c|c|c|c|c|c|c|c|}
\hline \multirow[b]{2}{*}{ Num } & \multirow[b]{2}{*}{ Question } & \multicolumn{4}{|c|}{ G city } & \multicolumn{4}{|c|}{$\mathrm{N}$ city } \\
\hline & & $\begin{array}{l}\text { Elementary } \\
\text { school } \\
\text { students }\end{array}$ & $\begin{array}{l}\text { Middle } \\
\text { and } \\
\text { high } \\
\text { school } \\
\text { students }\end{array}$ & $\begin{array}{l}\text { Children } \\
\text { are } \\
\text { excluded } \\
\text { school }\end{array}$ & Sum & $\begin{array}{l}\text { Elementary } \\
\text { school } \\
\text { students }\end{array}$ & $\begin{array}{l}\text { Middle } \\
\text { and } \\
\text { high } \\
\text { school } \\
\text { students }\end{array}$ & $\begin{array}{l}\text { Children } \\
\text { are } \\
\text { excluded } \\
\text { school }\end{array}$ & Sum \\
\hline 1 & $\begin{array}{l}\text { Given the opportunity to work to participate } \\
\text { transforming the region. }\end{array}$ & 2.34 & 2.03 & 2.35 & 2.24 & 2.04 & 2.09 & 2.20 & 2.11 \\
\hline 2 & $\begin{array}{l}\text { Given the opportunity to participate in } \\
\text { planning or making decision for the region. }\end{array}$ & 2.31 & 2.00 & 2.14 & 2.15 & 1.96 & 2.04 & 2.17 & 2.06 \\
\hline 3 & $\begin{array}{l}\text { Local communities (local councils, heads of } \\
\text { local governments, etc.) think their opinions } \\
\text { on living conditions or areas. }\end{array}$ & 1.99 & 1.89 & 2.00 & 1.96 & 1.84 & 1.92 & 2.17 & 1.98 \\
\hline 4 & $\begin{array}{l}\text { I ask my opinion about the budget of } \\
\text { programs and services for children. }\end{array}$ & 2.18 & 1.87 & 2.00 & 2.02 & 1.75 & 1.77 & 2.16 & 1.89 \\
\hline 5 & $\begin{array}{l}\text { I have heard about children's rights through } \\
\text { various media (local TV, radio, publications, } \\
\text { festivals, events, etc.) }\end{array}$ & 2.44 & 2.07 & 2.21 & 2.24 & 2.06 & 2.17 & 2.19 & 2.14 \\
\hline 6 & $\begin{array}{l}\text { Through the Internet, I can learn about what } \\
\text { is happening inside and outside our } \\
\text { community. }\end{array}$ & 2.60 & 2.50 & 2.65 & 2.58 & 2.35 & 2.22 & 2.33 & 2.30 \\
\hline
\end{tabular}

※ Average score: $1=$ Not at all, $2=$ Sometimes, $3=$ Very.

$※$ Positive response rate: Percentage of responses to positive responses (very)

According to the analysis, the response of children in G city on 'regional society (local councils, heads of local governments, etc.) investigates my opinion on the living environment or region' in terms of the level of rights awareness of the areas of civic awareness and participation of children was the lowest, followed by 'Ask My Opinion on the Budget of Programs and Services for Children'. In the case of N city, 'Asking my opinion on the budget of programs and services for children' was the lowest, followed by 'the community (regional council, local government heads, etc.) investigates my opinion on the living environment or region.' Through these results, it is necessary to make efforts to improve the level of 
participation of children who are members of the community to develop them into child-friendly cities in the future.

\subsubsection{Perception of Prior Criminal Protection Areas}

Among the six areas of child-friendly cities, the level of rights recognition for safety and protection services is as follows. Safety and protection areas consist of items on the level of safety and protection felt in the community. The level of recognition of children's rights in the area is as shown in [Table 4].

[Table 4] The Level of Recognition of Children's Rights in the Area (Unit : \%)

\begin{tabular}{|c|c|c|c|c|c|c|c|c|c|}
\hline Num & Question & & $\mathrm{G}$ ci & & & & $\mathrm{N}$ ci & & \\
\hline $\begin{array}{l}\mathrm{N} \\
\mathrm{UM}\end{array}$ & question & $\begin{array}{l}\text { Elementary } \\
\text { school } \\
\text { students }\end{array}$ & $\begin{array}{c}\text { Middle } \\
\text { and } \\
\text { high } \\
\text { school } \\
\text { students }\end{array}$ & $\begin{array}{l}\text { Children } \\
\text { are } \\
\text { excluded } \\
\text { school }\end{array}$ & Sum & $\begin{array}{l}\text { Elementary } \\
\text { school } \\
\text { students }\end{array}$ & $\begin{array}{c}\text { Middle } \\
\text { and } \\
\text { high } \\
\text { school } \\
\text { students }\end{array}$ & $\begin{array}{l}\text { Children } \\
\text { are } \\
\text { excluded } \\
\text { school }\end{array}$ & Sum \\
\hline 1 & $\begin{array}{l}\text { I know where to report and who to ask for } \\
\text { help when there is a danger to me. }\end{array}$ & 2.93 & 2.82 & 2.67 & 2.81 & 2.88 & 2.81 & 2.67 & 2.79 \\
\hline 2 & I feel safe from gangsters/arms. & 2.53 & 2.54 & 2.54 & 2.54 & 2.55 & 2.62 & 3.00 & 2.72 \\
\hline 3 & $\begin{array}{l}\text { I feel safe from violence and } \\
\text { abuse.*linguistics, physical, or sexual } \\
\text { violence and abuse. }\end{array}$ & 2.58 & 2.55 & 2.33 & 2.49 & 2.56 & 2.65 & 3.00 & 2.74 \\
\hline 4 & I feel safe from kidnapping & 2.47 & 2.46 & 2.24 & 2.39 & 2.53 & 2.50 & 3.00 & 2.68 \\
\hline 5 & $\begin{array}{l}\text { I'm not worried about being bullied by my } \\
\text { friend. }\end{array}$ & 2.42 & 2.57 & 2.59 & 2.53 & 2.56 & 2.58 & 2.33 & 2.49 \\
\hline 6 & $\begin{array}{l}\text { I feel safe from dangerous drugs (e.g., drugs, } \\
\text { hallucinogens, etc.) }\end{array}$ & 2.64 & 2.69 & 2.63 & 2.65 & 2.65 & 2.63 & 2.33 & 2.54 \\
\hline 7 & $\begin{array}{l}\text { I feel safe from dangerous drugs (e.g., drugs, } \\
\text { hallucinogens, etc.) }\end{array}$ & 2.47 & 2.42 & 2.32 & 2.40 & 2.56 & 2.63 & 3.00 & 2.73 \\
\hline 8 & $\begin{array}{l}\text { Children are respected regardless of race, } \\
\text { religion, nationality, ethnicity, culture and } \\
\text { disability. }\end{array}$ & 2.67 & 2.51 & 2.30 & 2.49 & 2.74 & 2.74 & 2.67 & 2.72 \\
\hline 9 & $\begin{array}{l}\text { Public transportation (e.g. buses, subways, } \\
\text { etc.) is safe for me to use. }\end{array}$ & 2.71 & 2.67 & 2.68 & 2.69 & 2.43 & 2.60 & 3.00 & 2.68 \\
\hline 10 & $\begin{array}{l}\text { There is an adult (other than my family) who } \\
\text { I can ask for help with abuse or violence }\end{array}$ & 2.87 & 2.68 & 2.65 & 2.73 & 2.74 & 2.74 & 2.67 & 2.72 \\
\hline 11 & $\begin{array}{l}\text { Protect me from doing dangerous things } \\
\text { (e.g., unsafe things that threaten my health) }\end{array}$ & 2.76 & 2.55 & 2.43 & 2.58 & 2.58 & 2.56 & 2.67 & 2.60 \\
\hline 12 & $\begin{array}{l}\text { Tell me how to behave safely in a disaster } \\
\text { situation (e.g., floods, earthquakes, etc.). }\end{array}$ & 2.76 & 2.51 & 2.52 & 2.60 & 2.62 & 2.54 & 2.67 & 2.61 \\
\hline 13 & $\begin{array}{l}\text { Teach me the problems about the adverse } \\
\text { effects of the Internet. *selective/violent } \\
\text { content, illegal downloads, hacking, } \\
\text { malicious comments, etc. }\end{array}$ & 2.72 & 2.33 & 2.21 & 2.42 & 2.36 & 2.31 & 2.00 & 2.22 \\
\hline 14 & $\begin{array}{l}\text { Provide homeless children with a place to } \\
\text { eat, wash and sleep. }\end{array}$ & 2.55 & 2.37 & 2.33 & 2.42 & 2.25 & 2.32 & 2.00 & 2.19 \\
\hline
\end{tabular}

$※$ Average score: $1=$ Not at all, $2=$ Sometimes, $3=$ Very.

$※$ Positive response rate: Percentage of responses to positive responses (very)

The analysis showed that the overall response rate to 'I feel safe from kidnapping' was low in terms of the level of rights awareness for the safety and protection of children living in G city, followed by 'safe to walk or ride a bicycle'. In the case of $\mathrm{N}$ city, the response rate to 'provide a place for homeless children to eat, wash and sleep' was the lowest, followed by 'teaching me the problems with the adverse 
effects of the Internet.' Given the above results, the future creation of a child-friendly city requires efforts to create a safe physical environment, along with the positive provision of security-related housing or proper use of media.

\subsubsection{Recognition of Health and Social Services Areas}

Among the six areas of child-friendly cities, the level of rights recognition for detailed health and social services is as follows. The health and social service areas consist of questions about medical services and environmental services in the community. The level of children's rights recognition in that area is as shown in Table 5 .

[Table 5] The Level of Recognition of Children's Rights in the Area (Unit : \%)

\begin{tabular}{|c|c|c|c|c|c|c|c|c|c|}
\hline \multirow[b]{2}{*}{ Num } & \multirow[b]{2}{*}{ Question } & \multicolumn{4}{|c|}{ G city } & \multicolumn{4}{|c|}{$\mathrm{N}$ city } \\
\hline & & $\begin{array}{c}\text { Elementary } \\
\text { school } \\
\text { students }\end{array}$ & $\begin{array}{l}\text { Middle } \\
\text { and } \\
\text { high } \\
\text { school } \\
\text { students }\end{array}$ & $\begin{array}{l}\text { Children } \\
\text { are } \\
\text { excluded } \\
\text { school }\end{array}$ & Sum & $\begin{array}{c}\text { Elementary } \\
\text { school } \\
\text { students }\end{array}$ & $\begin{array}{l}\text { Middle } \\
\text { and } \\
\text { high } \\
\text { school } \\
\text { students }\end{array}$ & $\begin{array}{l}\text { Children } \\
\text { are } \\
\text { excluded } \\
\text { school }\end{array}$ & Sum \\
\hline 1 & $\begin{array}{l}\text { I know about child mental health services } \\
\text { (e.g., counseling, etc.). }\end{array}$ & 2.52 & 2.28 & 2.41 & 2.40 & 2.17 & 2.18 & 2.00 & 2.12 \\
\hline 2 & I can get sex education through experts.. & 2.66 & 2.50 & 2.38 & 2.51 & 2.40 & 2.41 & 2.33 & 2.38 \\
\hline 3 & $\begin{array}{l}\text { There's a public toilet I can use safely and } \\
\text { easily. }\end{array}$ & 2.37 & 2.30 & 2.59 & 2.42 & 2.22 & 2.33 & 2.33 & 2.29 \\
\hline 4 & $\begin{array}{l}\text { There is no problem with garbage and } \\
\text { dirty water. }\end{array}$ & 2.13 & 2.22 & 2.21 & 2.19 & 2.13 & 2.20 & 2.33 & 2.22 \\
\hline 5 & $\begin{array}{l}\text { There is an emergency facility available } \\
\text { when I am hurt or sick. }\end{array}$ & 2.87 & 2.75 & 2.52 & 2.71 & 2.43 & 2.39 & 3.00 & 2.61 \\
\hline 6 & $\begin{array}{l}\text { There is no problem with smoke and } \\
\text { odour and it is clean. }\end{array}$ & 2.06 & 2.13 & 2.27 & 2.15 & 2.08 & 2.12 & 2.67 & 2.29 \\
\hline 7 & $\begin{array}{l}\text { There's a place where I can get a } \\
\text { checkup or see a doctor when I'm sick. }\end{array}$ & 2.89 & 2.82 & 2.70 & 2.80 & 2.65 & 2.64 & 2.67 & 2.65 \\
\hline 8 & I get the necessary vaccine & 2.87 & 2.72 & 2.63 & 2.74 & 2.66 & 2.58 & 2.67 & 2.64 \\
\hline
\end{tabular}

※ Average score: $1=$ Not at all, $2=$ Sometimes, $3=$ Very.

※ Positive response rate: Percentage of responses to positive responses (very so)

According to the analysis, the response rate to 'no problems caused by smoke and odors' was the lowest in terms of the level of rights awareness of the health and social service sectors of children living in $\mathrm{G}$ city, followed by 'no problems caused by waste and dirty water'. In the case of $\mathrm{N}$ city, the response rate for 'I know about child mental health services (e.g., counseling)' was the lowest, followed by 'no problems caused by waste and dirty water'. Looking at the above results, the result is that while the level of medical care provided by the community is satisfied, the problems caused by environmental pollution treatment such as smoke and odors and garbage and dirty water are not satisfied. Active efforts are needed to resolve future environmental problems in the community caused by environmental pollution treatment such as smoke and odors and garbage and dirty water are not satisfied. 


\subsubsection{Awareness of the Educational Environment Area}

Among the six areas of child-friendly cities, the level of rights recognition for detailed education environment services is as follows. The education environment area consists of items related to services for public education. The level of children's rights recognition for the area is as shown in Table 6 .

[Table 6] The Level of Recognition of Children's Rights in the Area (Unit : \%)

\begin{tabular}{|c|c|c|c|c|c|c|c|c|c|}
\hline \multirow[b]{2}{*}{ Num } & \multirow[b]{2}{*}{ Question } & \multicolumn{4}{|c|}{ G city } & \multicolumn{4}{|c|}{$\mathrm{N}$ city } \\
\hline & & $\begin{array}{l}\text { Elementary } \\
\text { students }\end{array}$ & $\begin{array}{l}\text { Middle } \\
\text { and } \\
\text { high } \\
\text { school } \\
\text { students }\end{array}$ & $\begin{array}{l}\text { Children } \\
\text { are } \\
\text { excluded } \\
\text { school }\end{array}$ & Sum & $\begin{array}{l}\text { Elementary } \\
\text { students }\end{array}$ & $\begin{array}{l}\text { Middle } \\
\text { and } \\
\text { high } \\
\text { school } \\
\text { students }\end{array}$ & $\begin{array}{l}\text { Children } \\
\text { are } \\
\text { excluded } \\
\text { school }\end{array}$ & Sum \\
\hline 1 & I go to school. & 3.00 & 2.95 & 1.26 & 2.40 & 3.00 & 2.95 & 1.67 & 2.54 \\
\hline 2 & $\begin{array}{l}\text { I can buy basic school supplies (e.g., } \\
\text { notebooks, notebooks, books, etc.) for } \\
\text { school when I need them. }\end{array}$ & 2.95 & 2.92 & 2.50 & 2.79 & 2.93 & 2.92 & 2.33 & 2.73 \\
\hline 3 & $\begin{array}{l}\text { I can convey my opinion to the important } \\
\text { decision to process of the school. }\end{array}$ & 2.81 & 2.57 & 1.84 & 2.41 & 2.53 & 2.54 & 2.33 & 2.47 \\
\hline 4 & $\begin{array}{l}\text { When I want, I get enough attention and } \\
\text { help from my teacher. }\end{array}$ & 2.82 & 2.70 & 2.17 & 2.56 & 2.69 & 2.68 & 2.33 & 2.57 \\
\hline 5 & $\begin{array}{l}\text { Teated men and women equally in our } \\
\text { school. }\end{array}$ & 2.71 & 2.43 & 2.10 & 2.41 & 2.60 & 2.57 & 2.33 & 2.50 \\
\hline 6 & $\begin{array}{l}\text { In my school, the teacher listens to my } \\
\text { opinion. }\end{array}$ & 2.85 & 2.66 & 2.00 & 2.50 & 2.75 & 2.69 & 1.67 & 2.37 \\
\hline 7 & $\begin{array}{l}\text { In our school, we teach about proper } \\
\text { living habits (e.g., eating habits, etc.). }\end{array}$ & 2.80 & 2.65 & 2.08 & 2.51 & 2.77 & 2.54 & 1.67 & 2.33 \\
\hline 8 & $\begin{array}{l}\text { Our school teaches how to protect the } \\
\text { environment. }\end{array}$ & 2.82 & 2.63 & 2.04 & 2.50 & 2.73 & 2.51 & 1.67 & 2.30 \\
\hline 9 & We can get sex education in our school. & 2.85 & 2.70 & 2.33 & 2.63 & 2.73 & 2.60 & 1.67 & 2.33 \\
\hline 10 & $\begin{array}{l}\text { Our school has enough clean water to } \\
\text { drink and wash. }\end{array}$ & 2.79 & 2.79 & 2.36 & 2.65 & 2.79 & 2.70 & 1.67 & 2.39 \\
\hline 11 & $\begin{array}{l}\text { Our school has a toilet that is clean and } \\
\text { safe to use. }\end{array}$ & 2.59 & 2.58 & 2.04 & 2.40 & 2.49 & 2.52 & 1.67 & 2.23 \\
\hline 12 & $\begin{array}{l}\text { In our school we respect children } \\
\text { regardless of race, religion, nationality, } \\
\text { culture, etc. }\end{array}$ & 2.81 & 2.70 & 2.17 & 2.56 & 2.75 & 2.72 & 1.67 & 2.38 \\
\hline 13 & $\begin{array}{l}\text { In our school, children with disabilities } \\
\text { are respected, and treated the same. }\end{array}$ & 2.71 & 2.69 & 2.24 & 2.55 & 2.77 & 2.68 & 1.67 & 2.37 \\
\hline 14 & $\begin{array}{l}\text { Our school has experts (e.g., counselors) } \\
\text { who can talk about their worries }\end{array}$ & 2.69 & 2.74 & 2.25 & 2.56 & 2.81 & 2.76 & 1.67 & 2.41 \\
\hline 15 & $\begin{array}{l}\text { Children with disabilities can attend our } \\
\text { school. }\end{array}$ & 2.86 & 2.64 & 2.32 & 2.61 & 2.89 & 2.72 & 1.67 & 2.43 \\
\hline 16 & $\begin{array}{l}\text { Our school teaches children without } \\
\text { corporal punishment. }\end{array}$ & 2.77 & 2.45 & 2.15 & 2.46 & 2.69 & 2.59 & 1.67 & 2.32 \\
\hline 17 & $\begin{array}{l}\text { In our school, there is no risk of being } \\
\text { bullied or ostracized and we respect each } \\
\text { other. }\end{array}$ & 2.59 & 2.40 & 1.68 & 2.22 & 2.51 & 2.48 & 1.67 & 2.22 \\
\hline 18 & $\begin{array}{l}\text { In my school, the area where I live } \\
\text { provides programs for future jobs. }\end{array}$ & 2.74 & 2.66 & 2.14 & 2.51 & 2.52 & 2.58 & 2.33 & 2.48 \\
\hline 19 & $\begin{array}{l}\text { Our school has free time to play, } \\
\text { exercise, and rest with friends. }\end{array}$ & 2.91 & 2.70 & 2.33 & 2.65 & 2.91 & 2.75 & 2.33 & 2.66 \\
\hline 20 & $\begin{array}{l}\text { There is a library (including the school } \\
\text { library) available to me. }\end{array}$ & 2.95 & 2.88 & 2.50 & 2.78 & 2.93 & 2.79 & 2.33 & 2.68 \\
\hline
\end{tabular}




\begin{tabular}{|c|l|c|c|c|c|c|c|c|c|}
\hline 21 & $\begin{array}{l}\text { I learn about children's rights and the } \\
\text { United Nations Convention on the } \\
\text { Rights of the Child at school. }\end{array}$ & 2.46 & 2.02 & 1.87 & 2.12 & 2.37 & 2.22 & 2.33 & 2.31 \\
\hline 22 & $\begin{array}{l}\text { It supports me to attend school without } \\
\text { having to earn my own education fee. }\end{array}$ & 2.84 & 2.64 & 2.27 & 2.58 & 2.76 & 2.71 & 2.33 & 2.60 \\
\hline 23 & $\begin{array}{l}\text { There is a place where I can attend the } \\
\text { class }\end{array}$ & 2.88 & 2.83 & 2.45 & 2.72 & 2.82 & 2.77 & 2.33 & 2.64 \\
\hline
\end{tabular}

※ Average score: $1=$ Not at all, $2=$ Sometimes, $3=$ Very.

$※$ Positive response rate: Percentage of responses to positive responses (very so)

The analysis showed that the response rate to 'I learn about children's rights at school and the UN Convention on the Rights of the Child' was the lowest in terms of the level of rights awareness in the educational environment of children living in $\mathrm{G}$ city, followed by 'In our school, there is no risk of being bullied or ostracized and we respect each other'. In the case of $\mathrm{N}$ city, the response rate for 'our schools do not risk being bullied or ostracized and respect each other' was the lowest, followed by the response rate for 'our schools have clean toilets that are accessible and safe to use.' Looking at the above results, education services on the level of education for children's rights should be provided. In creating a childfriendly city, it is necessary to not only provide education but also to recognize children's human rights. For their human rights to be respected, human rights education must also be provided in various ways.

\subsubsection{Awareness of the Home Environment Area}

Among the six areas of child-friendly cities, the level of rights recognition for detailed home environment services is as follows. The domain of the home environment consists of items on the family life. The level of children's rights recognition for the area is as shown in Table 7.

[Table 7] The Level of Recognition of Children's Rights in the Area (Unit : \%)

\begin{tabular}{|c|c|c|c|c|c|c|c|c|c|}
\hline \multirow[b]{2}{*}{ Num } & \multirow[b]{2}{*}{ Questions } & \multicolumn{4}{|c|}{ G city } & \multicolumn{4}{|c|}{$\mathrm{N}$ city } \\
\hline & & $\begin{array}{l}\text { Elementary } \\
\text { school } \\
\text { students }\end{array}$ & $\begin{array}{l}\text { Middle and } \\
\text { high school } \\
\text { students }\end{array}$ & $\begin{array}{l}\text { Children } \\
\text { are } \\
\text { excluded } \\
\text { school }\end{array}$ & Sum & $\begin{array}{l}\text { Elementary } \\
\text { school } \\
\text { students }\end{array}$ & $\begin{array}{l}\text { Middle and } \\
\text { high school } \\
\text { students }\end{array}$ & $\begin{array}{l}\text { Children } \\
\text { are } \\
\text { excluded } \\
\text { school }\end{array}$ & Sum \\
\hline 1 & $\begin{array}{l}\text { There's plenty of clean water in } \\
\text { my house for drinking }\end{array}$ & 2.97 & 2.94 & 2.84 & 2.92 & 2.98 & 2.92 & 3.00 & 2.97 \\
\hline 2 & $\begin{array}{l}\text { There is a clean toilet I can use } \\
\text { at my house or near my house. }\end{array}$ & 2.83 & 2.86 & 2.69 & 2.79 & 2.72 & 2.83 & 2.67 & 2.74 \\
\hline 3 & $\begin{array}{l}\text { There is enough water to wash } \\
\text { in my house.. }\end{array}$ & 2.97 & 2.95 & 2.84 & 2.92 & 2.96 & 2.91 & 3.00 & 2.96 \\
\hline 4 & $\begin{array}{l}\text { The air in my house is clean and } \\
\text { free from smoke and air } \\
\text { pollution. }\end{array}$ & 2.86 & 2.77 & 2.68 & 2.77 & 2.79 & 2.78 & 3.00 & 2.86 \\
\hline 5 & Able to use electricity. & 2.99 & 2.95 & 2.92 & 2.95 & 2.98 & 2.92 & 3.00 & 2.97 \\
\hline 6 & $\begin{array}{l}\text { My house is stay able to all } \\
\text { seasons. }\end{array}$ & 2.93 & 2.91 & 2.81 & 2.88 & 2.93 & 2.92 & 3.00 & 2.95 \\
\hline 7 & $\begin{array}{l}\text { My house is an economical and } \\
\text { sustainable place to live. }\end{array}$ & 2.94 & 2.89 & 2.62 & 2.82 & 2.86 & 2.88 & 3.00 & 2.91 \\
\hline 8 & There is enough space in my & 2.88 & 2.87 & 2.60 & 2.78 & 3.00 & 2.84 & 3.00 & 2.95 \\
\hline
\end{tabular}




\begin{tabular}{|c|l|l|l|l|l|l|l|l|l|}
\hline & $\begin{array}{l}\text { house (e.g., play area, study } \\
\text { room, bedroom). }\end{array}$ & & & & & & \\
\hline 9 & $\begin{array}{l}\text { My house is safe for me to live } \\
\text { in. }\end{array}$ & 2.94 & 2.91 & 2.69 & 2.85 & 2.82 & 2.89 & 3.00 & 2.90 \\
\hline
\end{tabular}

※ Average score: $1=$ Not at all, $2=$ Sometimes, $3=$ Very

$※$ Positive Response Rate: Percentage of responses to positive responses (very)

The analysis showed that the overall response rate for 'The air is clean and there is no smoke and air pollution' was the lowest in terms of the level of rights recognition for the home environment area of children living in $\mathrm{G}$ city, followed by 'my house or near the house has a clean toilet I can use'. In the case of $\mathrm{N}$ city, the response rate for 'There is a clean toilet I can use in or near my house' was the lowest, followed by the response rate for ' air is clean and there is no air Close phrase with quotation. Looking at the above results, children perceive that they are satisfied with the use of electricity and drinking water needed for home life, but their satisfaction with the pollution of smoke and air is relatively low. Efforts to supplement air quality and environmental pollution are needed for these results to be addressed in the future as children perceive that they are satisfied with the use of electricity and drinking water needed for home life, but, their satisfaction with the pollution of smoke and air is relatively low.

\subsection{Child-Friendly City Satisfaction Level}

The level of satisfaction in child-friendly cities was measured with the level of satisfaction in two questions. The highest level of satisfaction is seven points, and the lowest level of satisfaction is one point, with the result shown in table 8 .

[Table 8] With the Result (Unit : Point)

\begin{tabular}{|c|c|c|}
\hline Sortation & G city & N city \\
\hline Satisfaction with the residential area & 5.31 & 5.06 \\
\hline Satisfaction of life & 5.02 & 5.17 \\
\hline
\end{tabular}

※ A higher score on a 7-point scale means a high level of satisfaction

The analysis showed that children living in $\mathrm{G}$ and $\mathrm{N}$ cities both had a high level of satisfaction of five points or more for their satisfaction with their living areas. This confirms that children now have a level of satisfaction with their residential areas and a level of satisfaction with their lives. In terms of satisfaction with the area of residence, the satisfaction level of the children living in $\mathrm{G}$ city was higher than those children living in $\mathrm{N}$ city. In the case of the satisfaction level of living, the responses of children in $\mathrm{N}$ city was slightly higher than the responses of the children in $\mathrm{G}$ city.

\section{Conclusion}

In terms of child welfare, the concept of an environment for children, or "child-friendly city," has been established and is spreading throughout the region and around the world. Child Friendly Cities (CFC) is a city where the four universal rights of children: the right to live, to develop, to protect and to participate, are fully realized in accordance with the ideology of the United Nations Convention on the Rights of the Child. Given the need for child-friendly city certification in Korea, it began as a solution to the low birth rate and the inappropriate social environment of child-care in line with the development of children and the expansion of women's social advancement.

The purpose of this study is to examine how children perceive their rights and their satisfaction in life 
in the urban community environment, and to analyze in detail the six major areas of child-friendly cities so that they can be supplemented in a constructive and concrete way for child-friendly cities. First, the 505 respondents in G City consists of 277 (54.83\%) males and 228 (45.17\%) females, while in N City, the 918 children consists of 476 (51.80\%) males and 442 (48.20\%) females. Second, when comparing play and leisure areas, the lowest item in the case of $\mathrm{G}$ city was the absence of space available to children with physical disabilities. In the case of $\mathrm{N}$ city, various cultural and religious events were held where where the children could participate or watch was the lowest. As a result, the absence of space available to children with physical disabilities and the provision of participation in various cultural and religious programs were not high, so improvement and efforts are needed in the future. Third, when comparing the areas of participation and civic awareness, in G city, the lowest items are the communities (local councils, heads of local governments, etc.) that survey the children's opinions on the living environment or region, while in $\mathrm{N}$ city, the lowest is seeking the children's opinions on the budget of programs and services for children. This implies that efforts are needed to improve the level of participation of children who are members of the community. Fourth, when comparing safety and protection areas, the lowest item in the case of G city is 'I feel safe from kidnapping' and 'I provide a place for homeless children to eat, wash and sleep.' In order to create a child-friendly city, efforts are needed to create a safe physical environment along with positive provision of media usage. Fifth, in the area of health and social services, the lowest category in the case of $\mathrm{G}$ city was 'no problems caused by smoke and odor' and 'I know about child mental health services (e.g., counseling, etc.). Therefore, active efforts are needed to solve environmental problems in the community. Sixth, in the field of educational environment, G city's lowest category was 'I learn about children's rights at school and the UN Convention on the Rights of the Child,' and N city's case was 'We do not risk being bullied or ostracized and respect each other'.

Therefore, there is a need to provide self- awareness education for children's human rights, and in order for their human rights to be respected, they must provide various human rights education that requires respect for other people's human rights. Seventh, in the home environment area, the lowest category in G city was 'Our air is clean and there is no smoke and air pollution,' and in the case of $\mathrm{N}$ city, 'There is a clean toilet that I can use in my house or near my house.' Therefore, it is necessary to make efforts to supplement air quality and environmental pollution for children living in the area. Finally, the level of satisfaction in child-friendly cities was five points higher for both satisfaction with the area of residence and satisfaction with life for children living in $\mathrm{G}$ and $\mathrm{N}$ cities. Overall, elementary school students scored high in their home environment, educational environment, play and leisure, safety and protection, and participation. These results show that children's rights recognition education and support are effective for lower grades. It suggest the need to provide sustainable child-friendly services at the stage of child rights awareness and growth development. Senior students should be allowed to receive services on child-friendly cities through monitoring support and direct participation in establishing and strengthening rights education programs for children.

These results should consist of complex interventions and approaches to methods that conside various aspects of education, safety and protection, play and leisure, health and social services in terms of children's rights in the creation of friendly cities. The results of the study by Malone (2006) showed that the physical environment can be more easily experienced and grown, such as advanced transportation systems, efficient services, residential stability, and the use of drinking clean water and toilets, which are the positive aspects of urban environment in child-friendly cities. However, the negative aspects such as the narrow residential space, environmental pollution, lack of play space and indifference to community neighbors due to the overcrowded population support the results of he study of Riggio (2002), which stated that a city complex due to various crimes, violence, and traffic accidents in a dense area can become a place where children's lives are threatened. Therefore, this study is expected to improve the satisfaction of children's lives in the physical and mental health dimensions of children, providing various implications for practical improvements so that urban environments and communities 
can be perceived as positive aspects and opportunities are provided as essential factors for them to live as healthy and matured next generations. The study subjects are the children in the areas of $\mathrm{N}$ city and $\mathrm{G}$ city, so there may be some limitations in the representation of the sample. While it is focused on the children's rights, it has failed to consider the various variables affecting life satisfaction among children living in the cities.

\section{Reference}

[1] Child Poverty in Perspective: An Overview of Child Well-Being in Rich Countries, UNICEF Inocenti Research Centre, (2007)

[2] P. Christensen, M. O' Brien, Children in the City : Home, Neighbourhood and Community, Routledge, (2002)

[3] K. Malone, A Key Player in A Global Movement for Child Friendly Cities, Routledge, (2006)

[4] E. Riggio, Child friendly cities: good governance in the best interests of the child, Environment \& Urbanization, (2002), Vol.14, No.2, pp.45-58, https://doi.org/10.1177/095624780201400204

[5] S. Y. Hong, A study on the development and validation of assessment indicators for children and youth-friendly cities, Sookmyung Women's University Doctor dissertation, (2013)

[6] Child Well-Being in Rich Countries: A Comparative Overview, UNICEF Innocenti's Complete Catalogue of Research and Reports ,UNICEF Office of Research, (2013)

[7] T. H. Yoon, Regional Health Inequalities in Korea The Status and Policy Tasks, Journal of Critical Social Welfare, (2010), No.30, pp.49-77.

[8] K. Malone, "The future lies in our hands": children as researchers and environmental change agents in designing a child-friendly neighbourhood, Local Environment, (2013), Vol.18, No.3. pp.372-395, https://doi.org/10.1080/13549839.2012.719020

[9] M. Heurlin-Norinde, Children, Environment and Independent Mobility, IAPS 14 Book of Proceedings, This study forms part of the project Children - Traffic - Environment being carried out at the Stockholm Institute of Education.

[10] H. A. Kang, Poverty, Risky Environments of Disadvantageous Neighborhoods, and Adolescents' Depression and Anxiety, Korean Journal of Social Welfare Studies, (2010), Vol.41, No.3, pp.327-348, DOI : 10.16999/kasws.2010.41.3.327

[11] H. A. Kang, C. R. Noh, A study of regional effects on the self-concept of youth, Studies on Korean Youth, (2012), Vol.23, No.4, pp.101-129.

[12] Y. M. Kim, Analysis of Neighborhood Disorder Influences upon Adolescent Depression, Social Science Research, (2008), Vol.24, No.4, pp.29-50.

[13] K. Aminzadeh, S. Denny, J. Utter, T. L. Milfont, S. Ameratunga, T. Teevale, T. Clark, Neighbourhood Social Capital and Adolescent Self-reported Wellbeing in New Zealand: a Multilevel Analysis, Social Science \& Medicine, (2013), Vol.84, pp.13-21, DOI: 10.1016/j.socscimed.2013.02.012

[14] A. K. Ivert, M. T. Levander, Adolescents'Perceptions of Neighbourhood Social Characteristics -Is There a Corelation with Mental Health, Child Indicators Research, (2014), Vol.7, No.1, pp.177-192. 